\title{
Nueva etapa de la revista ARGO
}

El pasado mes de junio, el Museo Marítimo de Barcelona (MMB), reeditaba la revista ARGO (segunda época) con la colaboración de Sapiens Publicaciones. La misión de esta especializada publicación, de periodicidad bianual, es impulsar el estudio, conservación y divulgación de la cultura marítima, así como también ser lugar de encuentro de entidades, organizaciones y museos dedicados a la cultura marítima.

Silvia Dahl | Museu Marítim de Barcelona

URL <http://www.iaph.es/revistaph/index.php/revistaph/issue/view/4359>

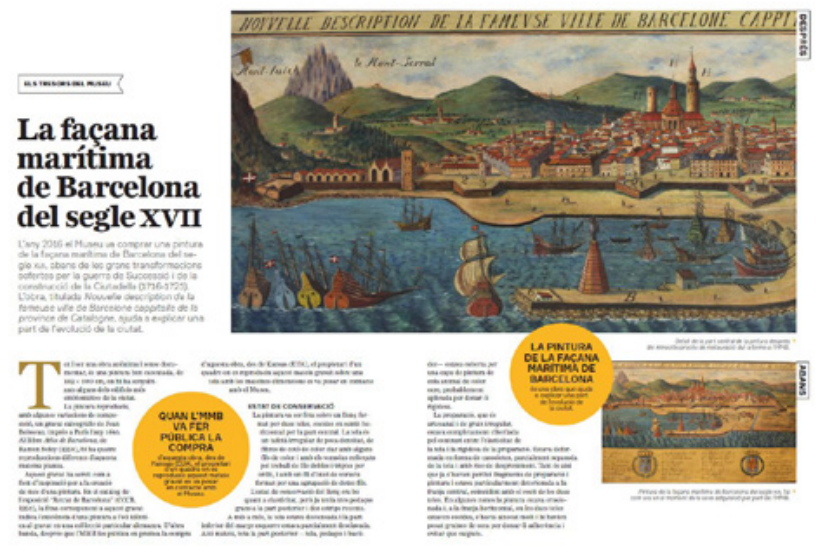

Revista ARGO. http://mmb.cat/

ARGO está destinada a quienes deseen sumergirse en el mar, a través de unas páginas escritas con rigor y con una cuidada imagen. El patrimonio marítimo abarca un extenso conjunto de temas, que explican las maravillosas complejidades del mar: la navegación tradicional y moderna, la pesca, la marina civil y militar, las actividades subacuáticas, así como los deportes náuticos. ARGO narra historias sobre personas y comunidades que protagonizan episodios históricos, explica la restauración de obras patrimoniales, se compromete en la protección y sostenibilidad de mares y océanos, y protege la recuperación de la memoria, entre otros contenidos.

La publicación se compone de secciones fijas. Entre ellas, un espacio dedicado a embarcaciones tradicionales con valor patrimonial, por ejemplo el pailebote Santa Eulàlia, una goleta centenaria que el Museu Marítim de Barcelona recuperó tras un intenso y riguroso trabajo de restauración. Los temas de actualidad social y medioambiental, como la crisis migratoria en el Mediterráneo o la contaminación de mares y océanos por plásticos, han sido abordados en los dos primeros números de esta segunda época de la revista. ARGO dedica un dossier central, de mayor extensión, a profundizar en aspectos de la cultura marítima. El del número 2 se ha centrado en la náutica deportiva y de competición, haciendo un recorrido histórico por la práctica de estos deportes desde sus inicios hasta la actualidad, y señalando la apuesta de futuro de un sector que trabaja por la accesibilidad en todos los sentidos, y que se señala como motor económico, generando una potente y vital industria.

Además la revista se ocupa de dar visibilidad a los estudios de conservación y restauración de objetos de la colección del Museo, como la intervención en una esfera armilar que proviene de la Escuela de la Marina Mercante de la Mediterránea, datada en el siglo XVIII, y atribuida a Charles-François Delamarche, o, más reciente, la restauración de una pintura de la fachada de Barcelona, del siglo XVII, adquirida en 2016, y que ayuda a explicar la evolución del frente marítimo de la ciudad.

ARGO también se encarga de la memoria oral, recogiendo testimonios, mediante entrevistas, de científicos, historiadores, navegantes e investigadores, entre otros perfiles. La entrevista al investigador Vicente GarcíaDelgado, sobre la memoria de la vela latina, es un documento que pone en valor una vida dedicada al estudio de estas embarcaciones. Otra sección destacada es la que dedica a personajes históricos que han dejado un legado de valor patrimonial, como José Pineda, uno de Ios mejores retratistas navales españoles del siglo XVIII autor de unas 3.000 obras, actualmente conservadas en colecciones públicas y privadas. 